\title{
PELAYANAN PASTORALIA TRANSFORMATIF UNTUK PENANGANAN MASALAH KEKERASAN SEKSUAL TERHADAP PEREMPUAN DI AMBON
}

\author{
Juliana Agusthina Tuasela dan Yohanes Parihala \\ Fakultas Teologi Universitas Kristen Indonesia Maluku \\ Jl. Ot Pattimaipauw Kota Ambon, Maluku, Indonesia \\ E-mail: tjulianadessy@yahoo.com
}

\begin{abstract}
This study is based on the fact that there are many problems of sexual violence against women in Indonesia in general, and in Ambon city in particular. The list of female violence in Indonesia is increasing significantly every year, both published and unpublished because of the hidden culture. This study aims to reveal the data of sexual violence occurring in urban communities, particularly Ambon, Desa Passo, and to find out the tragic stories experienced by victims, and to describe a transformative pastoral approach that can be conducted by the church to assist victims, as well as make awareness the perpetrators of the violence against women, which is not in accordance to the will of God. The study uses qualitative research methods and interview techniques as a means of gathering information/data to achieve research objectives. This study found that cases of violence against women tended to increase, and victims often silenced the case because of the culture of shame (hidden culture) to hide cases of violence in order not to be known by others. It is also the reason how the difficulty for law enforcement to the crime. Therefore, it needs a transformative pastoral approach to free the victims from the hidden culture and affirming the existence of the victim so that they can be healed from a prolonged traumatic experience.
\end{abstract}

Keywords:

Church; pastoralia; sexual violence; transformative; women.

\begin{abstract}
Abstrak
Penelitian ini berdasarkan pada kenyataan bahwa semakin banyak terjadi masalah kekerasan seksual terhadap perempuan di Indonesia, khususnya di kota Ambon. Daftar kekerasan perempuan di Indonesia meningkat secara signifikan tiap tahun, baik kekerasan yang terpublikasi maupun yang dibisukan karena faktor hidden culture (budaya malu). Penelitian ini bertujuan untuk menyingkap data kekerasan seksual yang terjadi di masyarakat perkotaan, khususnya Kota Ambon, di Desa Passo, dan mengetahui pengalaman tragis yang dialami para korban, serta menjelaskan suatu pendekatan pastoralia transformatif yang dapat dilakukan oleh gereja untuk mendampingi para korban, sekaligus menyadarkan para pelaku atas perbuatan kekerasan terhadap perempuan, yang tidak sesuai dengan kehendak Allah. Penulis menggunakan metode penelitian kualitatif dan teknik wawancara sebagai alat pengumpulan informasi/data untuk mencapai tujuan penelitian. Selanjutnya, penulis mengolah hasil kompilasi data secara deskriptif analitis dengan memakai teknik analisis data kualitatif, yaitu: reduksi data, display data dan menarik kesimpulan. Penelitian ini menemukan bahwa kasus kekerasan terhadap perempuan cenderung meningkat, dan para korban sering kali mendiamkan kasus tersebut karena budaya malu (hiden culture) sehingga menyembunyikan kasus kekerasan agar tidak diketahui pihak lain. Hal ini menyulitkan bagi proses penegakan hukum secara maksimal membongkar masalah tersebut. Oleh karena itu, dibutuhkan pendekatan pastoralia transformatif untuk membebaskan korban dari budaya menyembunyikan masalah kekerasan, dan meneguhkan eksistensi korban sehingga dapat dipulihkan dari pengalaman traumatis yang berkepanjangan.
\end{abstract}

Kata Kunci:

Gereja; Pastoralia; kekerasan seksual; perempuan; transformatif.

DOI: $10.15575 / \mathrm{jw} . \mathrm{v} 2 \mathrm{i} 2.1575$

Received: September 2017; Accepted: December 2017; Published: December 2017 


\section{A. PENDAHULUAN}

Permasalahan kekerasan terhadap perempuan menjadi isu kompleks di Indonesia. Komisi Nasional (Komnas) Perempuan mencatat dalam waktu 13 tahun terakhir (tahun 1998 - 2011) terdapat 400.939 kasus kekerasan terhadap perempuan. Dari seluruh jumlah kekerasan, 93.960 kasus dikategorikan sebagai kasus kekerasan seksual terhadap perempuan atau seperempat dari total kekerasan. Itu artinya setiap hari 20 perempuan menjadi korban kekerasan seksual. Tindakan perkosaan menempati jumlah terbanyak yakni 4.845 kasus. Dari 93.960 kasus kekerasan seksual terhadap perempuan, hanya 8.780 kasus datanya terpilah. Sisanya adalah gabungan dari kasus perkosaan, pelecehan seksual dan eksploitasi seksual. Sementara 8.784 kasus kekerasan seksual yang datanya terpilah, perkosaan menempati urutan pertama (4.845), berikutnya perdagangan perempuan untuk tujuan seksual (1.359), pelecehan seksual (1.049) dan penyiksaan seksual (672). Sisanya antara lain berupa eksploitasi seksual, perbudakan seksual hingga pemaksaan perkawinan. ${ }^{1}$

Dalam konteks Maluku, Lembaga Pemberdayaan dan Perlindungan Perempuan dan Anak (LAPPAN) Maluku menyatakan bahwa kekerasan seksual marak di Maluku, khususnya di Kota Ambon. ${ }^{2}$ Sepanjang tahun 2014, tercatat sebanyak 852 kasus kekerasan terhadap perempuan terjadi di Provinsi Maluku. Dari ratusan kasus tersebut, kasus kekerasan seksual lebih mendominasi dari jenis kasus kekerasan perempuan lainnya. Data LAPPAN menunjukkan tingkat kekerasan perempuan di Kota Ambon meningkat sangat tinggi sebanyak 96 kasus, disusul, Kabupaten Seram Bagian Barat (SBB): 68 kasus, Kabupaten

1 Khaerudin, "Perkosaan, Kekerasan Seksual Terbanyak Di Indonesia - Kompas.com," Kompas.com, diakses pada 2 Mei 2016, http://nasional.kompas.com/read/2011/11/24/21344444/Perkosaan.Kekeras an.Seksual.Terbanyak.di.Indonesia.

2 "Kekerasan Seksual Makin Marak Di Maluku," Dewan Maluku, diakses pada 2 Mei 2016, http://dewan.beritamalukuonline.com/2015/02/kekerasa n-seksual-makin-marak-di-maluku.html.
Maluku Tengah: 12 kasus, Kabupaten Maluku Tenggara: 3 kasus, Kabupaten Buru: 6 kasus. Data ini menggambarkan bahwa jenis kasus kekerasan seksual perkosaan berjumlah 31 kasus di semua wilayah, pencabulan berjumlah 23 kasus, kekerasan dalam pacaran berjumlah 11 kasus, pernikahan yang tidak diinginkan 5 kasus, percobaan perkosaan 18 kasus, eksploitasi seksual 6 kasus dan trafficking 3 kasus. $^{3}$

Deskripsi di atas menunjukkan bahwa angka dan bentuk kekerasan seksual terhadap perempuan ibarat fenomena gunung es. Secara faktual, jumlahnya bisa jauh lebih besar dan beragam dibanding kasus yang terdeteksi maupun dilaporkan kepada pihak yang berwenang. Pada sisi lain, terkesan ada kelambanan masyarakat dan ketidakseriusan aparat negara dalam menyelesaikan setiap kasus kekerasan. Kendati kekerasan seksual terhadap perempuan terjadi berulang dan terus menerus, tidak banyak masyarakat peka dan memahami ketimpangan sosial ini. Sikap membungkam sering dipilih sehingga kasus tidak terpublikasi. Budaya malu mengaku "aib" di hadapan publik menjadi penghambat kasus kekerasan seksual untuk dapat ditangani serius. Selain itu, peran pemerintah dianggap rendah dan tidak bermutu terhadap masalah kekerasan seksual perempuan. Pelayanan pemerintah tidak terintegrasi lintas institusi untuk menangani masalah ini. ${ }^{4}$

Permasalahan kekerasan terhadap perempuan adalah juga permasalahan yang dihadapi oleh gereja sebagai lembaga etik, moral dan spiritual di tengah kehidupan Bangsa Indonesia, masyarakat Maluku, dan khususnya Kota Ambon. Sensitivitas dan kesadaran gereja terhadap realitas ini adalah wujud panggilan kemanusiaan gereja dan pertanggung-jawaban

3 "852 Kasus Kekerasan Terhadap Perempuan Terjadi Sepanjang 2014," Kabar Timur Online, diakses pada 2 Mei 2016, 2018, http://www.kabartimur.co.id/detail/indeks/amboina/7378-852-kasuskekerasan-terhadap-perempuan-terjadi-sepanjang-2014.

4 "Kekerasan Seksual: Kenali Dan Tangani," Komnas Perempuan, diakses pada 7 mei 2013, www.komnasperempuan.go.id/kajian-kekerasanseksual-kenali-dan-tangani. 
iman kepada Tuhan. Pelayanan pastoralia transformatif adalah salah satu bentuk pembinaan gereja yang bisa dimanfaatkan untuk menangani masalah ini. Dalam perspektif gereja, ada beberapa alasan kekerasan seksual terhadap perempuan meningkat yaitu: perta$m a$, gereja dalam pembinaan umat mengabaikan pelayanan pastoralia kepada pelaku dan korban kekerasan seksual terhadap perempuan. Gereja cenderung ritualistik karena fokus pelayanan lebih terarah pada manajemen organisasi dan pelayanan ritual ibadah. Masalah kemanusiaan termasuk kekerasan seksual dianggap sebagai ranah pelayanan pemerintah. Kedua, gereja belum menemukan metode pelayanan pastoralia holistis dan terintegrasi terhadap masalah kekerasan seksual bagi perempuan. Ketiga, pelayanan pastoralia sebagai bagian dari pembinaan umat masih bersifat insidentiil dan tidak intensif menyentuh pelaku maupun korban kekerasan seksual.

Berdasarkan latar belakang masalah di atas, maka masalah penelitian yang menjadi fokus utama kajian ini adalah, bagaimana realitas kekerasan seksual terhadap perempuan di Ambon? Apa penyebab dan dampak kekerasan seksual terhadap perempuan di Ambon? Dan bagaimana aksi pelayanan pastoralia transformatif umat terhadap masalah kekerasan seksual perempuan di Ambon? Penelitian ini bertujuan untuk mengetahui bagaimana peran pelayanan pastoralia transformatif sebagai bagian dari pembinaan umat untuk menangani masalah kekerasan seksual terhadap perempuan. Tujuan tersebut didasarkan pula pada suatu hipotesis bahwa jika pelayanan pastoralia transformatif umat dijalankan secara baik dan tepat, maka jumlah dan dampak kekerasan seksual terhadap perempuan di Ambon semakin kecil.

Penelitian ini dilakukan di Kota Ambon, yang merupakan Ibu Kota Provinsi Maluku. Secara Khusus, Desa Passo, sebagai pusat kecamatan Baguala di Kota Ambon. Di lokasi ini, akses pelayanan publik, seperti pendidikan, hukum, pelayananan keagamaan, termasuk gereja, telah berkembang dengan baik. Namun, di tengah perkembangan masyarakat perkotaan seperti ini justru masalah kekerasan seksual terhadap perempuan memiliki trend dan kecenderungan yang meningkat.

\section{Konsep Kekerasan Seksual}

Konsep kekerasan seksual secara dasar menunjuk pada segala bentuk kekerasan seksual dan intimidasi seksual non-kekerasan. Tindakan perkosaan, histerektomi (operasi mengangkat rahim - yang tidak perlu), teror maupun eksploitasi perempuan via media adalah jenis terorisme seksual yang terdaftar. Terorisme seksual memosisikan perempuan dalam rasa takut, merasa dibenci dan didominasi pihak tertentu terutama kaum patriarki. Hacker menyatakan kekerasan seksual bisa dilakukan dengan tindak teror untuk menakutnakuti, dan berupaya mendominasi dan mengendalikan tubuh perempuan secara seksual. ${ }^{5}$

Jika seksualitas dilekatkan pada ide terorisme, maka ada lima komponen pokok, yakni: 1) Ideologi, yang melatari tindakan kekerasan seksual adalah ideologi patriarki. Patriarki berasal dari dua kata Yunani yakni pater dan arche yang artinya "pemerintahan para bapa". Sebagai suatu sistem sosial, patriarki mendasari ideologi seksisme dalam masyarakat. ${ }^{6}$ Laki-laki diposisikan superior dan perempuan inferior. Superioritas laki-laki melegalkan tindakan kekerasan terhadap perempuan. ${ }^{7}$ 2) Propaganda, yakni penyebaran informasi secara metodik untuk mengukuhkan ideologi tertentu. Propaganda didefinisikan sebagai informasi yang bias bahkan palsu. Propaganda adalah elemen esensial bagi terorisme. ${ }^{8}$ Propaganda terorisme seksual mengarah pada eksploitasi media budaya populer terhadap perempuan, yakni film, televisi, musik, literatur, iklan dan pornografi. Eksploitasi perempuan melalui peran budaya populer dikenal

5 Frederick J. Hacker, Crusader, Criminal and Crazies: Terrorism in Our Time (New York: W.W. Norton and Co., 1976), xi.

${ }^{6}$ Hope S. Antone, "Asian Women and Christianity," In God's Image - Journal of Asian Women's Resource Centre for Culture and Theology 28, no. 1 (2009), 26.

7 Carole J. Sehffield, "Terorisme Seksual," in Bentangkah Sayapmu - Hasil Seminar Dan Lokakarya Teologi Feminis (Jakarta: Persetia, 1999), 162.

${ }^{8}$ Sehffield, “Terorisme Seksual.", 163. 
dengan kekerasan simbolis. Kekerasan ini dimaknai sebagai bentuk penggunaan bahasa dan foto atau gambar perempuan di media dengan stereotype body and beauty, not the brain. ${ }^{9}$ 3) Kekerasan sewenang-wenang dan tidak bermoral, yang secara faktual berada pada pusat terorisme seksual. Setiap perempuan adalah target potensial kekerasan berapapun usianya, kapanpun dan di mana saja. Perilaku tidak bermoral yang mewarnai kekerasan seksual adalah pelecehan seksual terhadap anak-anak, ayah meniduri anaknya sendiri dan suami memukuli istri. Perlakukan tidak bermoral ini kadang tidak disadari. ${ }^{10} 4$ ) Ketaatan Sukarela, di mana kekerasan digunakan untuk mempertahankan terorisme. Sistem teror bernuansa kekerasan memperkuat ketaatan sukarela. Strategi diupayakan secara serius untuk menciptakan ketaatan sukarela. Pihak yang meneror adalah laki-laki dan perempuan diposisikan sebagai korban. ${ }^{11}$ 5) Persepsi tentang pelaku dan korban kekerasan, dalam kekerasan seksual, pihak yang dipersalahkan dan didiskreditkan adalah korban. Tindakan pembiaran terhadap pelaku merupakan hal lumrah. Dalam kondisi ini perempuan mengalami penindasan berlapis. ${ }^{12}$

\section{Metode Pastoralia Tansformatif}

Pencegahan dan penanganan masalah kekerasan seksual terhadap perempuan membutuhkan pendekatan pelayanan pastoralia yang holistis, intensif dan transformatif. Pelayanan pastoralia transformatif yang baik, membangun sensitivitas dan kesadaran umat tentang masalah ini serta mendorong peran semua pihak untuk mencegah maupun menanganinya.

Secara etimologi, istilah pastoral berasal dari bahasa Latin Pastor artinya gembala, sementara dalam Bahasa Inggris disebut Sepher. Istilah pastoralia biasa dipakai dalam gereja dengan istilah penggembalaan. Pelayanan pastoral adalah pelayanan mendampingi dan me-

\footnotetext{
${ }^{9}$ Idi Subandy Ibrahim, Kritik Budaya Komunikasi (Yogyakarta: Jalasutra, 2011), 270.

${ }^{10}$ Ibrahim, Kritik Budaya Komunikasi, 163.

${ }^{11}$ Ibrahim, Kritik Budaya Komunikasi, 164.

${ }^{12}$ Ibrahim, Kritik Budaya Komunikasi.
}

nguatkan orang yang bermasalah agar mampu menyelesaikan persoalannya. Menurut Joe Holland \& Peter Henriot SJ $^{13}$, jika masalah umat bersentuhan dengan masalah sosial, maka diperlukan pendekatan pastoralia transformatif yang disebut "Lingkaran Pastoral". Lingkaran itu menunjuk hubungan yang erat antara empat perantara pengalaman, yaitu: 1) Pemetaan Masalah, 2) Analisis Sosial, 3) Refleksi Teologis, dan 4) Perencanaan Pastoral. Empat unsur tersebut dapat digambarkan pada gambar 1.

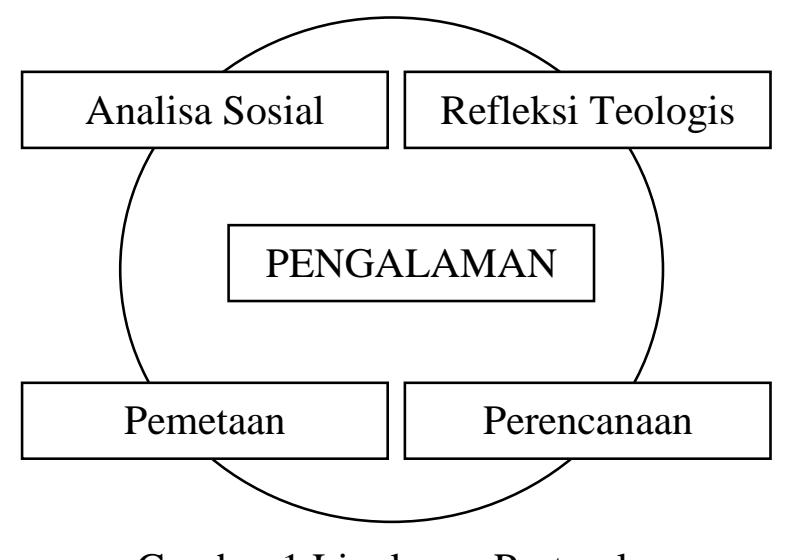

Gambar 1 Lingkaran Pastoral

Momen pertama, dalam lingkaran pastoral diawali dengan pemetaan masalah. Segi tersebut menempatkan letak geografis dari jawaban pastoral kita dalam pengalaman individu dan komunitas yang nyata. Apa yang dirasa, dialami dan bagaimana orang-orang menjawabnya merupakan pengalaman yang membentuk data pokok. Semua data pokok ini dihubungkan dengan pengalaman orang secara kolektif.

Momen kedua, momen kedua dalam lingkaran pastoral adalah analisis sosial. Analisis sosial menyelidiki sebab-sebab, akibat-akibat, menggambarkan kaitan-kaitannya dan mengidentifikasi pelaku-pelakunya. Pengalaman sosial mesti dipetakan secara baik dan menggambarkan titik hubungan yang satu dengan lainnya.

Momen ketiga, adalah theological reflection (refleksi teologis). Refleksi tersebut meru-

\footnotetext{
${ }^{13}$ Joe Holland dan Peter Henriot SJ, Analisis Sosial \& Refleksi Teologis - Kaitan Iman Dan Keadilan (Yogyakarta: Kanisius, 1994), 23-25.
} 
pakan upaya untuk memahami secara lebih luas dan mendalami pengalaman yang telah dianalisis dalam perspektif iman, Kitab Suci, Ajaran Gereja dan sumber-sumber tradisi. Sabda Tuhan yang terarah ke situasi konkret itu melahirkan pertanyaan-pertanyaan baru, memunculkan gagasan-gagasan baru dan membuka jawaban-jawaban baru.

Momen keempat yang teramat penting ialah pastoral planning (perencanaan pastoral). Tujuan lingkaran pastoral adalah melaksanakan putusan dan tindakan yang terwujud melalui perencanaan pastoral. Perencanaan pastoral dirumuskan berdasarkan hasil analisis dan refleksi terhadap pengalaman sosial. Tindakan pada situasi khusus melahirkan pengalamanpengalaman baru. Pengalaman tersebut menuntut perantara melalui pemetaan masalah, analisis, refleksi dan perencanaan. Jadi, lingkaran pastoral terus berkembang. Intinya, lingkaran pastoral ini lebih berupa gerak "spiral" ketimbang sebuah lingkaran. Tiap langkah tidak sekedar membaharui langkah-langkah terdahulu, tetapi mematahkan landasan baru.

\section{B. HASIL DAN PEMBAHASAN \\ 1. Pemetaan Masalah}

Penulis memakai pendekatan pastoralia transformatif untuk membahas permasalahan kekerasan seksual terhadap perempuan di Kota Ambon khususnya di Desa Passo. Kajian pastoralia transformatif ini dibingkai dengan 4 (empat) langkah dalam proses lingkaran praksis, yaitu: pertama, pemetaan masalah, kedua, analisa sosial, ketiga, refleksi teologis (theological reflection) dan keempat, perencanaan pastoral (planning pastoral). Kajian pastoralia transformatif disoroti dari perspektif feminis dengan melihat pengalaman perempuan menjadi sumber dan bahan berteologi. Pemikir feminis mesti sensitif terhadap suara, perasaan, pikiran maupun pengalaman seorang perempuan. J.B. Banawiratma menegaskan, upaya pembebasan perempuan mesti dibangun dari prinsip gender sensitivity training. ${ }^{14}$

14 J. B. Banawiratma, "Teologi Feminis Yang Relevan Di Indonesia," dalam Bentangkah Sayapmu -
Masalah kekerasan seksual terhadap perempuan merupakan masalah global. Dalam kajian pemetaan masalah secara spesifik diarahkan pada lokus masalah kekerasan perempuan dalam konteks nasional yang dapat dideskripsikan berdasarkan data yang dikeluarkan oleh Komisi Nasional Anti Kekerasan terhadap Perempuan (KOMNAS Perempuan). KOMNAS Perempuan mencatat angka kasus Kekerasan Dalam Rumah Tangga atau kekerasan Ranah Personal (RP) fluktuatif sepanjang satu dasawarsa $(2004-2013) .{ }^{15}$ Dalam laporan data terbaru dari Komnas Perempuan yang mengeluarkan Catatan Tahunan (Catahu) 2016 dan 2017 mencatat beragam kasus kekerasan terhadap perempuan yang terjadi sepanjang 2016 dan 2017. Menurut Ketua Komnas Perempuan, Azriana dari sisi pola, bentuk dan angka kekerasan terhadap perempuan semakin meluas. ${ }^{16}$ Selanjutnya, disebutkan hasil identifikasi data Komnas Perempuan menunjukkan, bahwa kekerasan tidak hanya terjadi di wilayah domestik, melainkan telah meluas di berbagai ranah termasuk di wilayah publik. Persoalan kekerasan perempuan bisa dibagi dalam 3 ranah, yakni wilayah relasi personal, komunitas dan negara. Berdasarkan jumlah kasus yang didapat dari 232 lembaga mitra Komnas Perempuan di 34 provinsi, terdapat 16.217 kasus tahun $2016^{17}$ dan ada 259.000 kasus tahun $2017^{18}$.

Hasil Seminar Dan Lokakarya Teologi Feminis (Jakarta: Persetia, 1999), 43.

15 Nur Rofiah, "Kekerasan Dalam Rumah Tangga Dalam Perspektif Islam," Wawasan: Jurnal Ilmiah Agama Dan Sosial Budaya 2, no. 1 (June 30, 2017), 33, doi:10.15575/jw.v2i1.829.

${ }^{16}$ Kristian Erdianto, "Komnas Perempuan Mencatat 16.217 Kasus Kekerasan Terhadap Perempuan Pada 2015," Kompas.com, diakses pada 7 Mei 2016, http://nasional.kompas.com/read/2016/03/07/17453241/ Komnas.Perempuan.Mencatat.16.217.Kasus.Kekerasan. terhadap.Perempuan.pada.2015.

${ }^{17}$ Kristian Erdianto, "Komnas Perempuan Mencatat 16.217 Kasus Kekerasan Terhadap Perempuan Pada 2015."

18 Ade Irmansyah, "Catahu 2017 Komnas Perempuan, Kekerasan Di Ranah Personal Tertinggi KBR," diakses pada 3 Januari 2017, http://kbr.id/beri- 
Deskripsi data sebagai berikut: pertama Ranah Personal: Kekerasan terhadap perempuan yang paling menonjol kekerasan terjadi di ranah personal. Catahu 2016 menunjukkan terjadi kenaikan data jenis kekerasan seksual di ranah personal dibanding tahun sebelumnya, yakni 11.207 kasus. Tahun 2017, kekerasan di ranah personal menempati urutan atas yaitu 255 ribu kasus. Bentuk kekerasan di ranah personal meliputi: kekerasan fisik, psikis, seksual, dan kekerasan ekonomi. Sedangkan untuk kekerasan di ranah rumah tangga/relasi personal (KDRT/RP) seperti kekerasan terhadap istri (KTI) menempati peringkat pertama 5.700an kasus, disusul kekerasan dalam pacaran (KDP) 2.100an kasus, kekerasan terhadap anak perempuan 1.700an kasus dan sisanya kekerasan mantan suami, kekerasan mantan pacar, serta kekerasan terhadap pekerja rumah tangga. ${ }^{19}$

Kedua Ranah Komunitas: Pada tahun 2016, di ranah komunitas, terdapat 5.002 kasus kekerasan terhadap perempuan. Sebanyak 1.657 kasus di antaranya jenis kekerasan seksual. Temanya meluas, yakni pekerja seks online, mucikari, selebriti pekerja seks, cybercrime, biro jodoh yang dinilai berkedok syariah, dan penyedia layanan perkawinan siri. ${ }^{20}$ Kekerasan di ranah komunitas mencapai angka 3.092 kasus. Kekerasan seksual menempati peringkat pertama sebanyak 2.290 kasus, diikuti kekerasan fisik 490 kasus dan kekerasan lain yaitu kekerasan psikis 83 kasus, buruh migran 90 kasus dan trafficking 139 kasus. Jenis kekerasan yang paling banyak pada kekerasan seksual di ranah komunitas adalah perkosaan (1.036 kasus) dan pencabulan (838 kasus). ${ }^{21}$

Ketiga, Ranah Negara: Pada tahun 2016, di ranah negara, aparat negara masih menjadi pelaku langsung atau melakukan pembiaran

ta/03-2017/catahu_2017_komnas_perempuan_kekerasan_di_ranah_personal tertinggi/89070.html.

19 Ade Irmansyah, "Catahu 2017 Komnas Perempuan, Kekerasan di Ranah Personal Tertinggi”

${ }^{20}$ Erdianto, "Komnas Perempuan".

21 Ade Irmansyah, "Catahu 2017 Komnas Perempuan, Kekerasan di Ranah Personal Tertinggi" pada saat peristiwa pelanggaran HAM terjadi. Komnas Perempuan mencatat ada 8 kasus yang melibatkan negara. Di antaranya 2 kasus pemalsuan akta nikah di Jawa Barat dan 6 kasus lainnya terjadi di Nusa Tenggara Timur terkait perdagangan orang atau trafficking. Pada kasus pelanggaran HAM masa lalu, terdapat kekerasan seksual dan stigmatisasi terhadap perempuan yang masih berlangsung hingga kini. ${ }^{22}$ Sementara di ranah negara yang paling menonjol tahun 2017 adalah kasus penggusuran. Komnas Perempuan mencatat ada kasus Cakung Cilincing di Jakarta sebanyak 1 kasus dengan 304 korban, kasus penggusuran Bukit Duri, Kampung Pulo dan Konflik SDA pembangunan pabrik Semen di Pegunungan Kendeng Jawa Tengah. Pulau Jawa disebutkan sebagai pulau dengan angka kekerasan terhadap perempuan tertinggi dengan 34 persen. $^{23}$ Data ini menunjukkan bahwa kasus kekerasan seksual memiliki prosentase tertinggi baik di ranah personal, komunitas maupun negara.

Peta kekerasan seksual kepada perempuan secara nasional, memiliki mata rantai masalah dengan konteks lokal di Maluku, khusus Kota Ambon di Desa Passo. Informasi yang disampaikan oleh Direktur Yayasan Lingkar Pemberdayaan Perempuan dan Anak (LAPPAN) Ambon, Baihajar Tualeka melalui berita Antara Maluku, disebutkan bahwa kasus kekerasan seksual di Maluku masih terbilang tinggi. Kekerasan seksual masih menjadi masalah yang belum ditemukan penyelesaian, termasuk di Maluku khusus Kota Ambon, angkanya masih tinggi. ${ }^{24}$

Baihajar mengungkapkan hasil pendataan kasus kekerasan yang dilaporkan dan ditangani oleh LAPPAN di Kota Ambon, Kabupaten Seram Bagian Barat, Maluku Tengah, Maluku Tenggara dan Pulau Buru dalam dua tahun

\footnotetext{
${ }^{22}$ Erdianto, "Komnas Perempuan".

${ }^{23}$ Irmansyah, "Catahu 2017 Komnas Perempuan, Kekerasan di Ranah Personal Tertinggi"

${ }^{24}$ Shariva Alaidrus, "Lappan Ambon: Kekerasan Sesksual Masih Tinggi," Antaranews, diakses pada 31 Agustus 2017, http://ambon.antaranews.com/berita/37493/lappan-ambon-kekerasan-seksual-masihtinggi.
} 
terakhir, sedikitnya ada 217 kasus yang terjadi pada 2015, dan 137 kasus di tahun 2016. Dari 354 kasus tersebut, 213 di antaranya adalah kejahatan seksual perkosaan sebanyak 77 kasus. Sedangkan 45 kasus lainnya adalah pelecehan seksual, dan 22 kasus percobaan perkosaan. Jika diurutkan berdasarkan jenis kasus, dari 24 kasus dengan konteks kekerasan dalam pacaran (KDP), terbanyak adalah perkosaan, percobaan perkosaan dan eksploitasi seksual. Begitu juga dengan kekerasan dalam rumah tangga (KDRT), terdapat 24 kasus pelecehan seksual yang terjadi pada istri atau anak perempuan. Tercatat sepanjang tahun 20152016, terdapat 11 kasus eksploitasi seksual lainnya, dan enam kasus perkawinan yang tidak diinginkan. Jumlah kasus yang ditangani tahun 2016 terlihat lebih sedikit dari pada tahun 2015, hal itu dikarenakan ada perbedaan rentang waktu dan wilayah dalam pendokumentasian dan pengumpulan data. Kasus kekerasan yang terjadi pada kurun waktu tahun 2015, berhasil dihimpun per Januari Desember di Kota Ambon, Kabupaten Seram Bagian Barat,

Maluku Tengah, Maluku Tenggara dan Pulau Buru. Secara sekilas kasus yang ditangani tahun 2016 lebih sedikit.
Itu tidak berarti jumlahnya berkurang karena tidak semua kasus tahun 2015 sudah selesai ditangani. Kasus yang ditangani pada tahun 2016 jadi lebih banyak karena bertambah dengan yang belum selesai pada tahun sebelumnya. ${ }^{25}$

Sebagai perbandingan data Lappan, penulis mengajukan data dari Yayasan Gaisira Maluku, suatu yayasan yang bergerak di bidang pemerhati perempuan dengan datanya mengenai kekerasan seksual terhadap perempuan dalam 3 (tiga) tahun terakhir, tahun 2015 - 2017. Yayasan ini melakukan survey dan pendampingan kepada korban masalah kekerasan seksual terhadap perempuan di Maluku khusus Kota Ambon, Desa Passo. Dalam 3 (tiga) tahun terakhir ada temuan kasus kekerasan seksual terhadap perempuan dengan 4 kategori berbeda yaitu: pertama, kasus kekerasan dalam pacaran, kedua, kasus trafficking, ketiga, kasus perkosaan dan keempat, pelecehan seksual seperti tergambar pada tabel 1 sampai tabel 3 berikut ini:

Tabel 1 Angka Kasus Kekerasan dalam Pacaran

\begin{tabular}{|c|c|c|c|c|c|}
\hline \multirow[t]{2}{*}{ No } & \multirow[t]{2}{*}{ Tahun } & \multicolumn{3}{|c|}{ Kasus Kekerasan dalam Pacaran } & \multirow{2}{*}{ Jumlah } \\
\hline & & Fisik & Seksual & Psikis & \\
\hline 1 & 2015 & 1 & - & - & 1 \\
\hline 2 & 2016 & - & 1 & - & 1 \\
\hline 3 & $\begin{array}{l}2017 \text { (Januari- } \\
\text { Juli) }\end{array}$ & - & - & - & - \\
\hline & TOTAL & 1 & 1 & - & 2 \\
\hline
\end{tabular}

Tabel 2 Angka Kasus Kekerasan dalam Trafficking

\begin{tabular}{ccccc}
\hline \hline No & Tahun & \multicolumn{2}{c}{ Kasus Kekerasan dalam Pacaran } & \multirow{2}{*}{ Jumlah } \\
\cline { 3 - 4 } & & Eksploitasi Ekonomi & Eksploitasi Seksual & \\
\hline 1 & 2015 & - & - & - \\
\hline 2 & 2016 & 2 & 7 & 9 \\
\hline
\end{tabular}

25 Alaidrus, "Lappan Ambon: Kekerasan Sesksual Masih Tinggi”. 
Pada tabel 1 terlihat bahwa kasus Kekerasan Dalam Pacaran (KDP), tidak menunjukkan angka perkembangan yang signifikan, tercatat hanya 1 kasus di tahun 2015 yang mengalami kekerasan fisik dan tahun 2016 ditemukan 1 kasus kekerasan seksual, tahun 2017 tidak ditemukan.

Kasus trafficking tergambar pada tabel 2 dengan dua kategori yaitu eksploitasi ekonomi dan eksploitasi seksual. Eksploitasi ekonomi ditemukan tahun 2016 sebanyak 2 (dua) kasus sedangkan pada tahun 2017 sebanyak 6 (enam) kasus. Sementara untuk eksploitasi seksual sebagai indikasi kekerasan seksual ditemukan tahun 2016 sebanyak 7 (tujuh) kasus, sedangkan pada tahun 2015 tidak ditemukan kasus.

Tabel 3 Kasus Perkosaan dan Pelecehan Seksual

\begin{tabular}{ccccc}
\hline \hline No & Tahun & \multicolumn{2}{c}{ Kasus Kekerasan Seksual } & Jumlah \\
\cline { 3 - 4 } & & Kasus Perkosaan & $\begin{array}{c}\text { Kasus Pelecehan } \\
\text { Seksual }\end{array}$ & \\
\hline 1 & 2015 & 66 & 13 & 79 \\
\hline 2 & 2016 & 33 & 40 & 73 \\
\hline 3 & $\begin{array}{c}2017 \\
\text { (januari-Juli) }\end{array}$ & 19 & 28 & 47 \\
\hline & 118 & 81 & 199
\end{tabular}

Tabel 3 menunjukkan bahwa dalam 3 (tiga) tahun terakhir, masalah kekerasan seksual mempunyai potensi meningkat setiap tahun. Tahun 2015 kasus perkosaan ditemukan sebanyak 79 kasus, tahun 2016 sebanyak 73 kasus dan pertengahan tahun 2017 antara bulan Januari - Juli sudah ditemukan sekitar 47 kasus. Kasus perkosaan ditotalkan sebanyak 118 kasus dan pelecehan seksual sebanyal 81 dengan keseluruhan kedua kasus berjumlah 199. Angka yang cukup tinggi dan perlu ditangani dan diputuskan mata rantai peningkatannya. Kalau ditemukan kasus dalam jumlah seperti ini, ada kemungkinan banyak kasus yang sama belum terakumulasi, karena kuatnya budaya malu dalam masyarakat. Gambaran data diatas merupakan representasi kuatnya potensi lestarinya praktek kekerasan seksual terhadap perempuan di Maluku, Kota Ambon khususnya Desa Passo.

Hasil penelitian di Desa Passo menunjukkan bahwa ada kesadaran dan pengakuan terhadap kasus kekerasan seksual terhadap perempuan. Desa Passo adalah desa di pusat Kecamatan Baguala, Kota Ambon. Karakteristik desa ini termasuk daerah perkotaan dengan masyarakat heterogen dan menjadi salah satu daerah pusat ekonomi, pemerintahan sekaligus sosial budaya di daerah Kecamatan Baguala. Realitas ini memberi ruang terjadi perjumpaan sosial, sekaligus menjadi potensi munculnya tindakan asusila seperti kekerasan seksual terhadap perempuan.

Dari hasil temuan, di Desa Passo khusus dalam pelayanan gereja, masalah kekerasan seksual terhadap perempuan dianggap masalah krusial dan perlu ditangani secara serius, tetapi secara riil gereja belum mampu membuat data secara akurat terkait masalah ini. Terindikasi hampir tidak ada data untuk memetakan dan mengidentifikasi masalah ini secara baik. Sebagian besar data ini ditemukan dari lembaga atau yayasan yang bergerak sebagai pemerhati masalah perempuan. Kesadaran atas masalah ini ada, tetapi gereja belum maksimal diberi ruang penanganan masalah oleh anggota jemaat. Alasannya adalah: pertama, budaya malu untuk menyampaikan masalah ini ke pihak gereja. Korban dan keluarga malu, aib diketahui pihak luar. Kedua, masalah ini dianggap sebagai kriminal yang menjadi tanggung- 
jawab pihak aparat penegak hukum. Kalau masalahnya telah diproses secara hukum, peran gereja tidak dibutuhkan lagi. Ketiga, orientasi gereja lebih banyak terarah pada masalah organisatoris dan ritual, kurang diberi perhatian yang besar untuk pelayanan masalah sosial seperti ini. ${ }^{26}$

\section{Analisa Sosial}

Kekerasan seksual merupakan isu penting dan kompleks dari peta kekerasan perempuan dan anak di Indonesia umumnya, Maluku secara khusus termasuk Kota Ambon, tepatnya Desa Passo. Merujuk pada konteks Desa Passo, penulis memfokuskan perhatian pada korban kekerasan seksual yaitu perempuan dan anak.

Hasil penelitian menunjukkan bahwa pada bulan januari - Juni 2017, di Kota Ambon ada sekitar 46 kasus di mana korban berusia sekitar 4-32 tahun. Korban sebagian besar adalah perempuan terutama anak. Korban umumnya berasal dari latar belakang keluarga yang memprihatinkan baik secara ekonomi maupun pendidikan yang lemah sehingga mudah dimanfaatkan. Kasus kekerasan seksual biasa terjadi di dalam rumah atau keluarga pelaku ketika tidak ada orang di rumah, di daerah pekuburan, institusi pendidikan, alat transportasi publik dan dalam berbagai konteks seperti konflik, migrasi, kekerasan atas nama agama, moralitas dan budaya. Biasanya kejadian di tempat sunyi di mana tidak ada orang. Korban jarang melapor kejadian ini, karena diancam. Kasus terungkap ketika orang tua mengamati perubahan sikap dari korban. $^{27}$ Dari semua kasus itu, pelaku berjumlah sekitar 47 orang, karena ada temuan satu kasus pelaku perkosaan adalah 2 (dua) orang yang notabene adalah teman korban. Pelaku berusia sekitar 19 - 74 tahun. Pelaku adalah orang-orang yang dekat dengan korban, yaitu paman korban, tetangga dan tukang ojek langganan. Faktor kedekatan itu memberi

${ }^{26}$ JT (korban), wawancara oleh Juliana A. Tuasela, Desa Passo, Tanggal 21 Juni 2017.

${ }^{27}$ NG (Korban), wawancara oleh Juliana A Tuasela, Desa Passo, Tanggal 30 Juli 2017. peluang terhadap kekerasan seksual terhadap perempuan. Kekerasan seksual dilakukan dengan modus rayuan materi berupa uang dan permen.

Kekerasan seksual terjadi secara berulang dan terus menerus, namun tidak banyak masyarakat peka dan memahami ketimpangan sosial ini. Kekerasan seksual dianggap sebagai kejahatan terhadap kesusilaan semata. Pandangan ini diabsahkan negara melalui muatan Kitab Undang-undang Hukum Pidana (KUHP). Pengkategorian ini mengurangi derajat perkosaan, sehingga tidak ditangani sebagai tindakan kriminalitas dalam litigasi hukum. Sikap membungkam juga sering dipilih sehingga kasus tidak terpublikasi. Budaya malu mengakui "aib" di hadapan publik menjadi penghambat kasus kekerasan tak pernah ditangani secara serius. ${ }^{28}$

Berdasarkan wawancara mendalam dengan korban, ada beberapa penyebab terjadi kasus kekerasan seksual terhadap perempuan, yaitu:

a. Kekerasan seksual jarang terungkap dan semakin lestari karena budaya malu dalam masyarakat yang kuat. Hidden culture (budaya tersembunyi) yang mengajarkan orang untuk merahasiakan dan menyembunyikan kasus ini kepada orang karena dianggap aib. Itu hanya masalah internal keluarga, yang tidak perlu terpublikasi. Orang dilarang membuka aib kepada orang lain. Perempuan dan anak menjalani ketaatan sukarela kendati ditindas kekerasan, hidup di bawah tekanan dan ancaman lelaki. ${ }^{29}$ Terindikasi kuat pembiaran dari korban.

b. Banyak gereja bersikap diam terhadap persoalan kekerasan seksual terhadap perempuan dan anak. Pembisuan dan pembiaran kekerasan perempuan adalah sikap pro ketidakadilan dan menyuburkan tindakan dehumanisasi. Program pelayanan gereja tidak memberi perhatian maksimal kepada korban kekerasan

\footnotetext{
28 "Kekerasan Seksual: Kenali Dan Tangani."

${ }^{29}$ Asnath N. Natar, Ketika Perempuan Berteologi Berteologi Feminis Kontekstual (Yogyakarta: Taman Pustaka Kristen, 2012), 133.
} 
seksual. Hasil penelitian menunjukkan sebagian besar korban tidak mendapat pelayanan pendampingan dan pastoralia dari gereja, justru yang melayani adalah lembaga sosial lainnya. ${ }^{30}$ Program gereja hanya terpusat pada urusan organisatoris dan ritualistik. Hal lainnya, sikap gereja seperti ini juga dilatari oleh sikap ketertutupan dari korban dan keluarga untuk menyembunyikan masalah ini. $^{31}$ Pelayanan pastoral tidak berjalan produktif bagi korban kekerasan seksual terhadap perempuan.

c. Legitimasi hukum Indonesia belum memberi akses bagi perempuan korban kekerasan. Kekerasan seksual dianggap sebagai kejahatan terhadap kesusilaan semata. Pandangan ini diabsahkan negara melalui muatan Kitab Undang-undang Hukum Pidana (KUHP). Pengkategorian ini mengurangi derajat perkosaan, sehingga tidak ditangani sebagai tindakan kriminalitas dalam legitimasi hukum.

d. Persoalan ketimpangan relasi kuasa antara pelaku dan korban adalah akar kekerasan terhadap perempuan. Ketimpangan relasi ini diperparah ketika satu pihak (pelaku) memiliki kendali lebih terhadap korban. Kendali ini bisa berupa sumber daya yakni pengetahuan, ekonomi juga status sosial. Termasuk kendali yang terbentuk dari hubungan patron-klien atau feodalisme seperti orangtua-anak, majikan-buruh, guru-murid, tokoh masyarakat-warga dan aparat negarapenduduk sipil. $^{32}$ Relasi kuasa yang mengisyaratkan ketimpangan sosial, karena ada pihak superior yang menggunakan kuasa menindas dan ada pihak lemah yang menerima penindasan dengan ketaatan sukarela.

\footnotetext{
${ }^{30} \mathrm{NG}$ (korban), wawancara oleh Juliana A. Tuasela, Desa Passo, Tanggal 30 Juli 2017.

${ }^{31}$ HL (korban), wawancara oleh Juliana A. Tuasela, Desa Passo, Tanggal 23 Juli 2017.

${ }^{32}$ HL (korban), wawancara oleh Juliana A. Tuasela, Desa Passo, Tanggal 23 Juli 2017.
}

e. Pembiaran tindakan kekerasan seksual dilatari karena masyarakat tidak sensitif dan tidak memahami esensi kekerasan seksual. Kekerasan seksual dianggap realitas sosial yang wajar dalam masyarakat sehingga dibisukan, bahkan korban menjadi pihak yang tidak dikenal. Pembisuan dan pembiaran kekerasan seksual merupakan bentuk keberpihakan terhadap ketidakadilan dan menumbuhkan suburnya tindakan dehumanisasi. Realitas ini juga dilegitimasi hukum Indonesia yang belum memberi akses cukup bagi perempuan korban kekerasan.

Selain penyebab kekerasan seksual, masalah ini juga membawa akibat bagi kejiwaan dan kehidupan sosial dari pihak korban.

a. Secara psikologis, kekerasan seksual memiliki dampak panjang dan pendek. Dalam jangka panjang, peristiwa ini dapat menimbulkan trauma yang berkepanjangan, bahkan hingga dewasa. Trauma akibat kekerasan seksual pada anak ini akan sulit dihilangkan kalau tidak secepatnya ditangani. Untuk jangka panjang, ketika dewasa nanti korban akan mengalami fobia pada hubungan seks atau bahkan yang parahnya lagi, korban akan terbiasa dengan kekerasan sebelum melakukan hubungan seksual. Bisa juga setelah menjadi dewasa, untuk seorang akan mengikuti apa yang dilakukan kepadanya semasa kecilnya. Dampak jangka pendeknya akan mengalami mimpi-mimpi buruk, ketakutan yang berlebihan pada orang lain, dan konsentrasi menurun yang akhirnya akan berdampak pada kesehatan.

b. Perempuan dan anak korban kekerasan akan menghadapi masalah dan penderitaan sehubungan dengan tindak kekerasan. Korban mengalami sanksi dan hukuman sosial, karena adanya diskriminasi dan stigmatisasi (kesan atau prasangka buruk dari masyarakat sekitarnya). Masalah diskriminasi dan stigmatisasi terhadap korban baik selama pemeriksaan medis maupun penyidikan harus dihindari sejauh mungkin untuk tidak menambah 
beban korban. Ada temuan, korban yang sementara bersekolah memilih untuk berhenti sekolah karena berada dalam rasa trauma dan malu menanggung stigma sosial. Ada rasa keterasingan sosial. Hukuman sosial ini bukan hanya berlaku bagi korban tetapi juga keluarga korban.

c. Korban mengalami penderitaan jasmani dan rohani, karena kekerasan seksual tersebut. Secara fisik, korban mengalami kehilangan keperawanan bagi yang masih perawan dan fisiknya terluka karena diperlakukan dengan tindakan tidak manusiawi. Secara rohani, korban merasa kehilangan harga diri, harkat dan martabat hidupnya sebagai manusia. Ia merasa hidupnya tercela dan tak layak bagi Tuhan maupun manusia. Kesucian hidupnya telah hilang dan ternodai.

d. Korban umumnya berada pada pihak yang lemah secara hukum karena ketentuan perundang-undangan di Indonesia yang mensyaratkan unsur-unsur pembuktian yang lengkap dan itu menambah trauma bagi korban. Korban dieksploitasi dan diinterogasi untuk mendapatkan buktibukti lebih lengkap. Eksploitasi psikis demi kepentingan tuntutan hukum.

\section{Refleksi Teologis}

Mengacu pada deskripsi dan hasil analisa di atas dirumuskan pikiran teologis yang bersumber dari tradisi Alkitab dan dialektikanya dengan konteks sosio-historis dapa dideskripsikan, sebagai berikut.

Kisah 2 Samuel 13: 1 - 37 merupakan salah satu bentuk kekerasan seksual yang dialami Tamar oleh saudara laki-lakinya Amnon. Kisah ini menempatkan Tamar sebagai korban kekerasan seksual dalam lingkungan domestik. Kekerasan seksual direncanakan secara sistematik karena hasrat seksual sebagai lakilaki. Otoritas Amnon sebagai kakak dan lakilaki yang kuat dipakai untuk meneror dan memerkosa Tamar. Amnon di posisi kuat dan Tamar pihak lemah yang menjalani pelecehan seksual.

Tamar menjadi objek pelampiasan seksual kakaknya Amnon. Cerita ini menampilkan sisi kesewenang-wenangan Amnon, saat hasrat seksual menggebu-gebu ia dapat memerkosa Tamar, namun di saat rasa benci kuat dengan sewajarnya bisa mengusir Tamar. Tamar membisukan pelecehan seksual itu, karena pelakunya adalah kakak kandungnya sendiri. Kisah Tamar adalah representasi korban terorisme seksual yang wajib diproteksi dan ditolong. Absalom tampil sebagai pembela Tamar dengan membunuh Amnon. Pertanyaan kritis, apakah kekerasan yang dibalas dengan kekerasan akan menyelesaikan masalah? Disfungsional keluarga Daud justru muncul dari mata rantai kasus pelecehan seksual ini. Menurut penulis kekerasan bukan cara final menyelesaikan masalah.

Allah berpihak kepada korban tetapi di sisi lain Allah juga mengupayakan penyadaran kepada pelaku. Korban dan pelaku kekerasan seksual dikasihi Allah. Keberpihakan Allah kepada korban bertujuan menguatkan korban dari kejatuhan moral sementara keberpihakan Allah kepada pelaku bertujuan menyadarkan pelaku dari kesalahan bukan wujud kompromi Allah terhadap kesalahan pelaku.

Penulis memakai ide teologi subaltern yang diajukan Felix Wilfred untuk mengkontekstualisasikan korban terorisme seksual. Teologi subaltern adalah metode dan orientasi menteologiskan setiap situasi lokal dengan isu konkrit. Teologi yang melihat realitas dan pengalaman korban dalam terang Injil. Korban menjadi agen terpenting dan utama. Teologi subaltern menggambarkan isu marjinalisasi dan subalternity dalam situasi lokal tetapi merefleksikan karakter universal. Artinya, realitas kekerasan seksual adalah masalah lokal dalam konteks tertentu tetapi imbasnya universal bagi seluruh masyarakat Indonesia. Korban kekerasan seksual adalah representasi subaltern dalam realitas sosial. Teologi subaltern mengakomodir suara dan kepentingan korban kekerasan yang selama ini dibisukan. Teologi subaltern merespon dan berkontribusi dari perspektif korban dari konstruksi sosial, politik dan budaya. Teologi subaltern membangun perjumpaan kekristen- 
an dengan pengalaman dan realitas konteks secara aktual. ${ }^{33}$

Matius 25:31 - 46 menghadirkan subalternity dalam konstruksi sosial yakni "orang yang lapar, orang yang haus, orang asing, orang telanjang, orang sakit dan orang terhukum". Beragam subalternity dengan tipikal berbeda. Yesus mengidentikkan diri dengan subalternity. Yesus adalah subalternity itu sendiri. Pesan moralnya, Yesus menyatu dengan penderitaan manusia yang terdiskriminasi, terhukum, terbuang dan diasingkan masyarakat. Teks ini menasehatkan pendengar dan pembaca saat ini untuk peka dan sadar begitu banyak subalternity di sekitar hidup kita yang perlu ditolong, dikasihi dan dilayani.

Kekerasan seksual dilatari kuat oleh budaya patriarki. Perempuan sebagai korban sering dibisukan dan tidak dikenal. Tindakan kekerasan laki-laki diabsahkan oleh hukum dan masyarakat. Bagaimana posisi Yesus menghadapi budaya patriarki yang dominan pada Yahudi? Komunitas Yahudi didominasi budaya patriarki membuat polarisasi laki-laki dan perempuan yang kuat. Budaya Yahudi memosisikan laki-laki superior dan perempuan inferior. Ajaran Yesus sangat revolusioner terhadap realitas ini. Pemberitaan Yesus senada dengan perbuatanNya. Yesus bergaul secara bebas dengan perempuan, Yesus bersahabat baik dengan perempuan (Yoh. 4:142), rombongan perempuan diizinkan bergabung dalam perjalanan Yesus dan mendukung Yesus (Lukas 24:10). Deskripsi tindakan di atas menunjukkan keberpihakan Yesus kepada perempuan dan menempatkan perempuan sejajar dengan laki-laki. ${ }^{34}$

Radikalisme Yesus membela perempuan berdasar pada kriteria baru yakni kasih. Yesus diperkenalkan sebagai nabi counter-culture. Setiap counter-culture membutuhkan komuni-

33 Felix Wilfred, "India and China for an Asian Subaltern Theology," dalam Herausforderung Im Dialog Der Religionen Und Kulturen, ed. Ludwig Bertsch dan Viele Wege - Ein Ziel (Freiburg: Herder, 2006), 50-51.

${ }^{34}$ S. Kapen, Jesus and Culture (Delhi: ISPCK, 2002), 15-16. tas penerus gagasan ini. Secara alamiah, Yesus memanggil laki-laki dan perempuan menjadi murid-Nya. Keberadaan Yesus bersama para murid bertujuan untuk mengidentifikasi diri-Nya yakni iman, harapan dan komitmen Yesus kepada orang banyak. Gereja sebagai bagian dari murid-murid Yesus diharapkan menghadirkan kerajaan Allah. ${ }^{35}$

\section{Perencanaan Pastoral}

Menyikapi realitas kekerasan, diskriminasi, eksploitasi dan penindasan perempuan maka pendampingan pastoral perempuan dan lakilaki mesti berbasis pembebasan. Dua dimensi pembebasan adalah: a). Perubahan budaya Barat menunjukkan secara signifikan perubahan status dan peran perempuan. Dua kekuatan besar yang perlu diubah demi pembebasan perempuan adalah sosialis dan westernisasi. b). Tujuan spesifik perempuan pada banyak negara dunia ketiga lebih terfokus pada ekonomi keluarga dan kurang terarah pada pembebasan seksual atau kemajuan individu. $^{36}$

Berdasarkan visi pembebasan, maka dapat dirancang-bangun suatu diskursus aksi pastoralia gereja khusus di Jemaat GPM Passo untuk mengantisipasi dan menangani kekerasan perempuan. Pertama, Gereja sebagai lembaga moral dapat memprogramkan pembinaan maupun pendidikan katekisasi dengan muatan "kekerasan terhadap seksual perempuan". Pastoralia secara kolektif maupun personal untuk membentuk sensitivitas dan kesadaran pelayan maupun umat tentang realitas kekerasan seksual terhadap perempuan. Kedua, perubahan paradigma tentang kesetaraan gender dapat disampaikan lewat berbagai muatan pembinaan dalam bina keluarga, beragam kategori bina (sekolah minggu, remaja, pemuda, laki-laki dan perempuan), materi katekisasi maupun Semiloka. Ketiga, gereja dapat melakukan proses pelatihan sensitivitas gender (gender sensitivity training)

\footnotetext{
${ }^{35}$ Kapen, Jesus and Culture, 16.

36 David W. Augsburger, Pastoral Counseling Across Cultures (Kentucky: Pastoral Counseling Across Cultures, 1986), 227.
} 
bagi warga gereja agar terlatih kepekaan dan kesadaran gender. Keempat, paradigma bergereja perlu terus diperbaharui dari penguatan institusi dan ritualistik ke pemberdayaan umat khusus tentang masalah sosial kemasyarakatan termasuk kekerasan seksual terhadap perempuan. Kelima, gereja menggalang pendampingan pastoralia holistis dengan melibatkan tenaga multi profesional baik psikiater, dokter, tokoh adat maupun tokoh masyarakat lainnya. Keenam, pelayan dan umat di jemaat GPM Passo perlu melakukan pendampingan pastoralia secara rutin dan intens dengan muatan pastoralia variatif kepada korban dan pelaku. Model pastoralia digagas secara kreatif secara kolektif maupun personal. Ketujuh, penguatan pastoralia dari Jemaat GPM Passo dengan mengadvokasi pelayan dan umat ke luar dari budaya malu dan menjadi budaya yang lebih terbuka untuk melakukan aksi pembelaan terhadap kasus kekerasan seksual.

\section{SIMPULAN}

Kajian teologi pastoralia mengenai masalah kekerasan seksual terhadap perempuan menunjukkan bahwa masalah tersebut adalah fakta sosial yang harus disikapi dan diminimalisasi. Tugas pembebasan gereja secara individu dan kelompok terhadap korban kekerasan merupakan wujud iman kepada Tuhan. Tuhan peduli dan berpihak untuk membebaskan kaum subalternity termasuk perempuan korban kekerasan. Kepedulian terhadap korban kekerasan bagian dari gerakan pembebasan. Gereja mesti berteologi dan membangun konsep pastoralia yang membebaskan. Segala bentuk kekerasan seksual ditentang Allah dan melanggar martabat kemanusiaan. Gereja sebagai representasi Kristus bertugas ganda terkait realitas ini yakni: pada satu sisi mesti berkomitmen menunjukkan keberpihakan kepada korban kekerasan seksual dan secara bersamaan juga mesti menunjukkan penerimaan kepada pelaku dan memberi penyadaran menuju pertobatan. Masalah kekerasan seksual memiliki mata rantai yang kompleks. Penanganan terhadap kasus ini membutuhkan itikad baik semua pihak. Komitmen yang dibangun atas dasar kasih dan kepedulian kepada sesama. Martabat kemanusiaan ditempatkan pada posisi tertinggi. Latar belakang apapun kehidupan seseorang, semua manusia dianugerahi hak dan martabat yang sama.

Gereja sebagai lembaga moral berkewajiban merumuskan program pembinaan yang memberi perhatian khusus kepada korban maupun pelaku kekerasan seksual terhadap perempuan. Gereja menjadi pioneer untuk menyuarakan dan melakukan tindakan advokasi dan pendampingan pastoralian secara transformatif kepada korban dan pelaku kekerasan seksual terhadap perempuan. Gereja merumuskan pelayanan pastoralia transformatif secara personal maupun kolektif dengan metode dan muatan pastoralia yang mampu mengantisipasi dan menangani masalah kekerasan seksual terhadap perempuan. Pastoralia holistis dengan melibatkan semua stakeholder yang mampu membawa pemabaruan positif dan konstruktif.

\section{UCAPAN TERIMA KASIH}

Artikel ini dikembangkan dari hasil penelitian yang telah dilakukan oleh penulis pada tahun 2017, yang didanai oleh Kementrian Riset, Teknologi dan Pendidikan Tinggi Republik Indonesia (Kemenristekdikti RI) melalui hibah penelitian dosen pemula. Oleh karena itu, penulis menyampaikan terima kasih kepada pihak Kemenristikdikti RI, yang telah membantu dan mendukung penelitian ini terutama melalui penyediaan dana penelitian yang diberikan. Semoga penelitian ini berkontribusi bagi pengembangan ilmu pengetahuan yang berdampak dalam kehidupan sosial kemasyarakatan. 


\section{DAFTAR PUSTAKA}

Antone, Hope S. "Asian Women and Christianity." In God's Image - Journal of Asian Women's Resource Centre for Culture and Theology 28, no. 1 (2009).

Augsburger, David W. Pastoral Counseling Across Cultures. Kentucky: Pastoral Counseling Across Cultures, 1986.

Banawiratma, J. B. "Teologi Feminis Yang Relevan Di Indonesia." In Bentangkah Sayapmu - Hasil Seminar Dan Lokakarya Teologi Feminis. Jakarta: Persetia, 1999.

Hacker, Frederick J. Crusader, Criminal and Crazies: Terrorism in Our Time. New York: W.W. Norton and Co., 1976.

Holland, Joe, and Peter Henriot SJ. Analisis Sosial \& Refleksi Teologis - Kaitan Iman Dan Keadilan. Yogyakarta: Kanisius, 1994.

Ibrahim, Idi Subandy. Kritik Budaya Komunikasi. Yogyakarta: Jalasutra, 2011.

Kapen, S. Jesus and Culture. Delhi: ISPCK, 2002.

Natar, Asnath N. Ketika Perempuan Berteologi - Berteologi Feminis Kontekstual. Yogyakarta: Taman Pustaka Kristen, 2012.

Rofiah, Nur. "Kekerasan Dalam Rumah Tangga Dalam Perspektif Islam." Wawasan: Jurnal Ilmiah Agama Dan Sosial Budaya 2, no. 1 (June 30, 2017): 31-44. doi:10.15575/jw.v2i1.829.

Sehffield, Carole J. "Terorisme Seksual." In Bentangkah Sayapmu - Hasil Seminar Dan Lokakarya Teologi Feminis, 158-86. Jakarta: Persetia, 1999.

Wilfred, Felix. "India and China for an Asian Subaltern Theology." In Herausforderung Im Dialog Der Religionen Und Kulturen, edited by Ludwig Bertsch and Viele Wege - Ein Ziel. Freiburg: Herder, 2006.

\section{INTERNET}

"852 Kasus Kekerasan Terhadap Perempuan Terjadi Sepanjang 2014." Kabar Timur Online. Diakses pada 3 Mei 2017. http://www.kabartimur.co.id/detail/indeks/a mboina/7378-852-kasus-kekerasanterhadap-perempuan-terjadi-sepanjang2014.

Ade Irmansyah. "Catahu 2017 Komnas Perempuan, Kekerasan Di Ranah Personal Tertinggi - KBR.” Diakses pada 3 Januari 2017. http://kbr.id/berita/03-2017/catahu_2017_komnas_perempuan_kekerasan_ di_ranah_personal tertinggi/89070.html.

Alaidrus, Shariva. "Lappan Ambon: Kekerasan Sesksual Masih Tinggi." Antaranews. Diakses pada tanggal 31 Agustus 2017. http://ambon.antaranews.com/berita/37493/ lappan-ambon-kekerasan-seksual-masihtinggi.

"Kekerasan Seksual: Kenali Dan Tangani." Komnas Perempuan. Diakses pada 7 Mei 2013. www.komnasperempuan.go.id/kajian-kekerasan-seksual-kenali-dan-tangani.

"Kekerasan Seksual Makin Marak Di Maluku." Dewan Maluku. Diakses pada 3 Januari 2017. http://dewan.beritamalukuonline.com/2015/02/kekerasan-seksualmakin-marak-di-maluku.html.

Khaerudin. "Perkosaan, Kekerasan Seksual Terbanyak Di Indonesia - Kompas.com." Kompas.com. Accessed January 3, 2018. http://nasional.kompas.com/read/2011/11/2 4/21344444/Perkosaan.Kekerasan.Seksual. Terbanyak.di.Indonesia.

Kristian Erdianto. "Komnas Perempuan Mencatat 16.217 Kasus Kekerasan Terhadap Perempuan Pada 2015." Kompas.com. diakses pada 7 Mei 2016. http://nasional.kompas.com/read/2016/03/0 7/17453241/Komnas.Perempuan.Mencatat. 16.217.Kasus.Kekerasan.terhadap.Perempu an.pada.2015. 
WAWANCARA

ML (korban/15 Tahun), Siswa di SMK Kesehatan Kelas X. Wawancara oleh Juliana Agusthina Tuasela. Desa Passo. Tanggal 23 Juli 2017.

JT (16 Tahun). Siswa SMA Kelas XI. Wawancara oleh Juliana Agusthina Tuasela. Desa Passo. Tanggal 21 Juni 2017.
HL (15 Tahun), Siswa SMA Kelas X. Wawancara oleh Juliana Agusthina Tuasela. Desa Passo. Tanggal 23 Juli 2017. IS (12 Tahun) Kelas 1 SMP. Wawancara oleh Juliana Agusthina Tuasela. Desa Passo. Tanggal 21 Juni 2017. 